\title{
A PERIDOMESTIC POPULATION OF THE TSETSE FLY Glossina palpalis palpalis ROBINEAU-DESVOIDY, 1830 (DIPTERA:GLOSSINIDAE) AT KONTAGORA TOWN, NIGER STATE, NIGERIA
}

\author{
A. B. Ahmed
}

\section{Resumo}

Uma população peridoméstica de moscas tsetse Glossina palpalis palpalis Robineau-Desvoydy, 1830 (Diptera: Glossinidae) na cidade de Kontagora, estado de Niger, Nigéria - $O$ artigo aborda alguns aspectos das populações peridomésticas das moscas tse-tsé Glossina palpalis palpalis Robinezu-Desvoidy, 1830 em Kontagora, Nigéria. Foi caracterizado um comportamento anormal deste vetor e que é de importância epidemiológica significante. Dados sobre a ecologia foram obtidos em 1995 e 1999. Os resultados indicam que esse vetor ocorre durante as estações seca e chuvosa; aproximadamente $30 \%$ dos exemplares estavam repletos de sangue, resultando em um MHS de 2,4, indicando uma população bem alimentada. Dissecação de pares inseminados indicam uma porcentagem de fertilidade de aproximadamente $30 \%$ e $70 \%$ nas estações seca e chuvosa e, a presença de todos os 4 estágios de fertilidade sugere que os criadouros se mantém em ambas as estações. A longevidade das moscas é de aproximadamente 16 dias na estação seca e 25 dias na chuvosa. Os resultados mostram que a relação vetor/hospedeiro é alta e que a população das moscas tem se adaptado, se desenvolvendo ativamente na área estudada. $O$ índice de infecção de 18,2\% consiste de uma tipo-brucei e 5 tipo-vivax. São discutidas as implicações na saúde pública da grande proximidade dos hospedeiros

Entomology \& Parasitology Division, Nigerian Institute for Trypanosomiasis Research (NITR), P.M.B. 2077, Kaduna, Nigeria. Tel: 234 (0)8023760544, 234 (62) 371753

E-mail:adoahmed2001@yahoo.com.

Recebido em: 05/01/2004.

Aceito em: 03/11/2004. 
naturais silvestres do parasita humano T.b. gambiensi Dutton, 1902 no parque Kainji Wild Life.

Palavras-chave: Glossina palpalis palpalis, comportamento peridoméstico, Trypanosoma brucei, Kontagora, Nigéria

\section{Abstract}

The present article considers some aspects of a peridomestic population of the tsetse fly Glossina palpalis palpalis Robineau-Desvoidy, 1830 in Kontagora, Nigeria. This situation characterizes an abnormal behaviour of the vector, and it is of significant epidemiological importance. Data on the ecology of this species were collected in 1995 and 1999. The results indicated that the species exists during both dry and wet seasons; approximately $30.0 \%$ of the catches were gorged with blood giving a MHS of 2.4, indicating a well-nourished population. Dissection of inseminated pars indicated pregnancy rates of approximately $30.0 \%$ and $70.0 \%$ in the dry and wet seasons and the presence of all 4 stages of pregnancy, suggesting that breeding occurs at both seasons. Longevity of flies was approximately 16 days in dry season and 25 days in the wet season. Overall results indicated that vector/host contact was high and the fly population has adapted and actively breeding in the area. Trypanosome infection rates of $18.2 \%$ consist of 1 brucei-type and 5 vivax-type infections. The public health implications of the close proximity of the wild natural reservoir hosts of the human T. b. gambiense Dutton, 1902 parasites at the Kainji Wild Life park is discussed.

Key words: Glossina palpalis palpalis, peridomestic behaviour, Trypanosoma brucei, Kontagora, Nigeria

\section{Introduction}

Members of the subgenus Nemorhina (The Palpalis group) are the principal vectors of human sleeping sickness in Nigeria (Nash, 1944; Omoogun et al., 1995). Their distribution is strictly within riverine vegetation and permanent pools of water except in the wet season when they dis- 
perse outside their habitat following increase in humidity. A few workers observed deviations from this typical ecological behaviour: Kernaghan (1961) in Gboko, Benue Province; Davies (quoted in Glover, 1961) at Malumfashi, Katsina Province and Baldry $(1964 ; 1970)$ at Nsukka, Eastern Nigeria. All these observations were on Glossina tachinoides Westwood, 1850. Since then, little further investigation was made except for Adeyemi \& Esuruoso (1997) who recently reported a peridomestic population of G. palpalis at Ibadan.

G. p. palpalis Robineau-desvoidy, 1830 and G. tachinoides Westwood, 1850 were observed in a plant nursery of the Directorate of Foods, Roads and Rural Infrastructure (DFRRI) within Kontagora township (NITR/NARP Unpublished reports) during the dry season of April, 1994, but this had remained an isolated observation: 5 G. p. palpalis and 2 G. tachinoides were caught during that survey. When 24 G. p. palpalis were caught during a $24 \mathrm{hr}$ survey of the same area during the wet season in October 1995, it was definitely established that the fly had adapted peridomestic behaviour in the area. The increase in resurgence in all aspects of human sleeping sickness across Africa (Arbyn et al., 1995; More \& Richer, 2001; Stanghellini \& Josenado, 2001) underline the considerable importance of the observations made on the peridomestic behaviour of the riverine species of tsetse in Nigeria. This paper is based on the observations made in the above-mentioned surveys and more detailed ecological investigations made in the dry season, March 1999. Although no further visit was made to the area since then, it is felt that the observations so far made were sufficiently interesting to be worth reporting. Such abnormal behaviour of the vector is rare in northern Nigeria and is of significant epidemiological relevance (Nash, 1944; Nash \& McDonald, 1959; Nash, 1960) because the majority of human sleeping sickness cases are reported in the northern part of the country.

\section{Materials and Methods}

\section{Study area}

The DFFRI nursery farm is located at the heart of Kontagora town (Latitude $10^{\circ} 24^{\prime} \mathrm{N}$ and Longitude $5^{\circ} 27^{\prime} \mathrm{E}$ ), Kontagora Local Government Area (LGA). It is boarded to the northeast by several mango trees with 
almost closed canopy that provide cool dense shade where the local people spend several hours daily relaxing. To the south, a small stream fringed with shrub-like vegetation flows eastwards; about 100m further downstream is a crossing point for people and livestock. The people wash and bath further downstream.

\section{Tsetse sampling}

The tsetse population was sampled using biconical (Chalier \& Larviessier, 1973) and nitse (Omoogun, 1994) traps. All flies caught were identified to species level (Potts, 1970; Davies, 1977; Pollock, 1982) and sexed. Females were dissected (Saunders, 1962; Challier, 1965) and agedgraded using the mean temperature of the area substituted into the formulae of Glasgow (1963) as applied by Phelps \& Vale (1978). For comparative purposes, females were also aged by the wing-fray method (Baldry \& Van der Vloedt, 1982), which was also used for male flies. All caught flies were then classified into different physiological categories (Jackson, 1933; Nash \& Page, 1953; Pollock, 1982) before dissecting for trypanosome infections (Penchenier \& Itard, 1981). Mean Hunger Stage (MHS) was computed using the method of Potts (1970).

\section{Results}

In 1994, both G. p. palpalis and G. tachinoides were reported in the area. Of the 5 G. p. palpalis caught, 2 were males and 3 females while the 2 G. tachinoides were males. The hunger stage of the flies caught in 1994 was not stated, but 5 of the 7 flies were non-tenerals indicating that they had taken a blood meal.

A total of $28.6 \%$ and $30.3 \%$ of the catches respectively in 1995 and 1999, were fully gorged with blood, giving a Mean Hunger Stage (MHS) of 2.5 and 2.3 respectively (Tab. I). 92.3\% of the 13 females dissected in 1995 had mating scars and had been fully inseminated while the value of $100 \%$ was obtained in 1999. Pregnancy rate and pregnancy stages of the females dissected in 1995 and 1999 are presented in table II.

The mean age of 1995 male samples from wing-fray method was 15 days, and 29 days for 1999 male samples (Tab. III). Age analysis for the females was 19 days in 1995, and 31 days in 1999 using ovarian method. 
Table I

Physiological categories of Glossina species at Kontagora town, Nigeria

\begin{tabular}{c|c|c|ccccc}
\hline \multirow{2}{*}{ Year } & \multirow{2}{*}{$\begin{array}{c}\text { No flies } \\
\text { caught }\end{array}$} & \multirow{2}{*}{$\begin{array}{c}\% \\
\text { females }\end{array}$} & \multicolumn{5}{|c}{ Physiological categories (\%) } \\
\cline { 4 - 8 } & & $\mathbf{G}$ & $\mathbf{R}$ & $\mathbf{I}$ & $\mathrm{H}$ & Preg. \\
\hline 1995 & 24 & 54.2 & $6(28.6)$ & $3(14.3)$ & $\mathbf{8 ( 3 8 . 1 )}$ & $5(23.8)$ & $7(29.2)$ \\
1999 & 39 & 59.0 & $10(30.3)$ & $3(9.1)$ & $10(30.3)$ & $10(30.3)$ & $16(69.6)$ \\
\hline
\end{tabular}

G-Gorged; R-Replete; I-Intermediate; H-Hungry; Preg-Pregnant; NA-Not available.

Table II

Pregnancy stages of Glossina palpalis palpalis at Kontagora town, Nigeria

\begin{tabular}{c|c|c|c|c|c}
\hline \multirow{2}{*}{ Year } & \multirow{2}{*}{$\begin{array}{c}\text { No } \\
\text { dissected }\end{array}$} & \multicolumn{5}{|c}{ Uterine content } \\
\cline { 3 - 6 } & & Egg & $1^{\text {st }}$ larva & $2^{\text {nd }}$ larva & $3^{\text {rd }}$ larva \\
\hline 1995 & 13 & 3 & 1 & 2 & 1 \\
1999 & 23 & 7 & 5 & 2 & 2 \\
\hline
\end{tabular}

Substituting the mean temperature of $24.1^{\circ} \mathrm{C}$ and $27.6^{\circ} \mathrm{C}$ recorded in 1995 and 1999, respectively into the formulae of Glasgow (1963) and using the dissection results of the females (Sauders, 1962; Challier, 1965), the age of the overall female populations and specific age at different ovarian cycles were estimated following the method of Phelphs \& Vale (1978). In 1995 female samples, a mean age of 15.7 days was obtained, lower than 20.2 days for 1999 sample. Maximum estimated age attained by females in 1995 (dry season) was 20.8 days and 44.2 days in 1999 (wet season). The pooled mean of the age estimates by the wing-fray and ovarian methods is accepted as a reasonable mean age of G. p. palpalis samples: 16.4 days in 1995 and 25.1 days in 1999 (Tabs. III \& IV).

None of the 22 non-tenerals dissected in 1995 had trypanosome infections, but $6(18.2 \%)$ of the 33 dissected in 1999 were positive: $1(16.7 \%)$ of the infection was brucei-type and 5 (83.7\%) vivax-type.

\section{Discussion}

Most of the detailed ecological studies on peridomestic behaviour of tsetse flies in Nigeria are on G. tachinoides. Reports on G. p. palpalis are 
Table III

Ageing of samples of G. p. palpalis using the wing-fray technique

\begin{tabular}{|c|c|c|c|c|}
\hline \multirow{3}{*}{ Wing-fray } & \multicolumn{4}{|c|}{ Year } \\
\hline & \multicolumn{2}{|c|}{1995} & \multicolumn{2}{|c|}{1999} \\
\hline & Males & Females & Males & Females \\
\hline $1 \mathrm{~A}$ & 1 & 1 & 3 & 3 \\
\hline $1 \mathrm{~B}$ & 8 & 4 & 3 & 5 \\
\hline 2 & 2 & 8 & 3 & 4 \\
\hline 3 & 0 & 0 & 2 & 4 \\
\hline 4 & 0 & 0 & 2 & 3 \\
\hline 5 & 0 & 0 & 2 & 3 \\
\hline 6 & 0 & 0 & 1 & 1 \\
\hline Total & 11 & 13 & 16 & 23 \\
\hline $\mathrm{MWFV}^{*}$ & 2.1 & 2.5 & $3.7^{* \star}$ & 3.9 \\
\hline \multicolumn{2}{|c|}{ MWFV $(\mathrm{M}+\mathrm{F})$} & & \multicolumn{2}{|c|}{3.8} \\
\hline \multicolumn{2}{|c|}{ Mean age (days) } & & \multicolumn{2}{|c|}{30} \\
\hline
\end{tabular}

* Mean Wing Fray Value (MWFV) of $2.1=15$ days (from Table of Jackson, 1948)

${ }^{* *}$ MWFV of $3.7=29$ days (see Table of Jackson, 1948)

Table IV

Age determination of female G. p. palpalis using ovarian analysis

\begin{tabular}{|c|c|c|c|c|c|}
\hline \multicolumn{3}{|c|}{1995} & \multicolumn{3}{|c|}{1999} \\
\hline Ov. Cat. & $\begin{array}{c}\text { Est. age } \\
\text { (days) }\end{array}$ & No flies & Ov. Cat. & $\begin{array}{c}\text { Est. age } \\
\text { (days) }\end{array}$ & No flies \\
\hline 0 & 7.5 & 5 & 0 & 6.4 & 7 \\
\hline 1 & 20.8 & 8 & 1 & 17.2 & 7 \\
\hline 2 & 32.3 & 0 & 2 & 26.2 & 4 \\
\hline 3 & 43.8 & 0 & 3 & 35.2 & 3 \\
\hline 4 & 55.3 & 0 & 4 & 44.2 & 2 \\
\hline \multicolumn{2}{|l|}{ Total } & 13 & \multicolumn{2}{|l|}{ Total } & 23 \\
\hline \multicolumn{3}{|c|}{ Mean age $=15.7$ days } & \multicolumn{3}{|c|}{ Mean age $=20.2$ days } \\
\hline
\end{tabular}

Ov. Cat $=$ Ovarian categories; Est. age $=$ Estimated age.

scanty, although the species appears to have adapted atypical behaviour in many other countries (Gouteux \& Larvessiere, 1982; Gouteux et al., 1983). At Mali, the presence of riverine species within urban Bamako town in mango plantations resulted in a serious sleeping sickness problem (Toure, 1974). Similarly, in Ivory Coast and Cameroon (Challier, 1973), tsetse adopted 
peridomestic behaviour in cocoa and coffee plantations leading to sleeping sickness outbreaks. Jordan (1989) observed that the change in the behaviour of the Nemorhina group (generally associated with watercourses and lakeside environments) is brought about by the destruction of their natural habitats taking place towards the drier and wetter limits of their distribution. The process, which is continuing with unprecedented speed, is resulting in the replacement of the natural vegetation with man-made habitats acceptable to the flies. Although, the resultant effect is not a general increase or decrease in the overall area infested by these species. It is nevertheless making the species to become resilient and closely adapted to atypical habitats, such as the situation in Kontagora town.

While studying transmission of Rhodesian sleeping sickness in the Lambwe valley, Kenya, Otieno (1982) observed four environmental conditions required to establish peridomestic behaviour by a population of G. pallidipes Austen, 1903, as suitable environmental temperature, high humidity, presence of shade/shelter and suitable food source. If the above requirements are similar for the G. p. palpalis of the Kontagora area, its occurrence in both dry and wet seasons may be an indication of fulfillment of the above conditions. The presence of old (parous) and young (nullipars and young pars) flies is a further indication that the biotype constitutes a complete habitat for the species, satisfying the ecological requirements of the different age groups.

Flies of different physiological categories were caught, comprising $12.7 \%$ tenerals and $25.0 \%$ gorged with blood. Although blood meal analysis was not conducted to ascertain the feeding pattern, man, cattle and small ruminants are common feature of the area. The presence of gorged flies in the catches further confirm the availability of animal hosts in the area, even though such segment of the population are rare in trap catches (Ahmed et al., 2000). Okoth (1999) observed in Uganda that the preference of a peridomestic population of G.f. fuscipes Newstead, 1910 for man and cattle made it a dangerous vector for sleeping sickness, even at a low fly density.

The presence of tenerals and older non-tenerals suggest danger in terms of acquisition and transmission of trypanosomes. Wijers (1958) observed that infections are easily acquired, particularly of the bruceitype when the first blood meal is infected, while chances of transmitting infections is higher in non-tenerals, especially those old enough to have allowed the development of the parasites to infective stages. The results 
of ageing indicated a population of approximately 16 days old in 1995 and 25 days in 1999. The possibility of the flies becoming infected with human infective parasites thus seems limited during the wet season because after acquiring the infections, the flies need to live long enough for the parasites to develop to infective transmissible stages. On the other hand, the flies are capable of supporting human trypanosomes during the dry season because developmental cycle last about 18 days in the vector. In terms of livestock trypanosomosis, the presence of T. vivax Ziemann, 1905 in the flies is a potential danger to the domestic ruminants as well; irrespective of the season, the fly population is capable of supporting this species as a minimum incubation period in the vector is 5 days (Desowitz \& Fairbain, 1955).

Although only one of the six infections was of the brucei-type, its presence nevertheless is of significance since the detection of bruceitype infection in wild tsetse is a rare occurrence in Nigeria (Onah \& Onyeka, 1985; Madubunyi, 1987; Kalu, 1991; Ahmed, et al., 2000). No attempt was made in this study to characterise this isolate, however, detection of one positive out of 6 infections from a small sample of 39 flies may indicate the existence of possible adventitious hosts. This area is contiguous with the Kainji Wild Life Park that harbours several species of wild game, the natural reservoir hosts of the disease. It is a traditional focus for human sleeping sickness; 340 persons diagnosed positive out of 3509 examined in Kankara district and 136 positive from 391 in Usalle district; in 1936. In 1961, $14.7 \%$ of the 34 persons examined at Auna district were positive for the disease (NITR unpublished epidemiological records).

Ecology of peridomestic population of tsetse is little known, therefore further investigation is required to understand the epidemiology of the disease as a prelude towards improving vector control.

\section{Acknowledgments}

I acknowledge the financial support of the World Bank assisted NARP project during surveys in 1994 and 1995. I thank the Research and Field staff of NITR that participated in the fieldwork, and the Director of NITR, Dr. I. Halid mni for his permission to publish. 


\section{References}

Adeyemi, I. \& Esuruoso, G.O.,1997. City resident tsetse: preliminary epizootiological investigations in Ibadan, south-western Nigeria. Epidemiol. Sante Anim. 1:31-32.

Ahmed, A.B.; Omoogun, G.A. \& Shaida, S.S., 2000. Trypanosome infections in Glossina species at the Kainji Wild Life Park, Nigeria. Entomol. Soc. Nig. Occ. Publ. 32:57-62.

Arbyn, M; Bruneel, H.; Molisho, S. \& Ekwanzala, F., 1995. Human trypanosomiasis in Zaire: a return to the situation at the beginning of the century?. Arch. Pub. Health 53:365-371.

Baldry, D.A.T., 1964. Observations on a close association between $G$. tachinoides and domestic pigs near Nsukka, Eastern Nigeria II. Ecology and trypanosome infection in G. tachinoides. Ann. Trop. Med. Parasitol. 58:32-44.

Baldry, D.A.T., 1970. Observations on peridomestic breeding behaviour and resting sites of Glossina tachinoides Westwood, near Nsukka, East Central State, Nigeria. Bull. Entomol. Res. 59:585-593.

Baldry, D.A.T. \& Vloet van der, A.M.V., 1982. A modified wing-fray anaysis technique for age estimation of Glossina. Procceedings of Symposium on Radiation in Insect Control 225/56: 185-190.

Challier, A.,1965. Amelioration de la methode de determination de'lage physiologique de glossines. Bull. Soc. Path. Exoc. 58:250-259.

Challier, A., 1973. Ecologie de Glossina palpalis gambiense Vanderplanck, 1949 (Diptera: Muscidae) en savanne d'Afrique occidentale. Mem. ORSTOM. 64:1-290.

Challier, A. \& Larveissiere, C., 1973. Un nouveau piege pour la capture des Glossines (Glossina: Diptera, Muscidae) description et essais sur le terrain. Cah. ORSTOM. ser. Entomol. Med. Parasitol. 11:251-262. 
Davies, H., 1977. Tsetse flies in Nigeria. Oxford University Press, lbadan. $340 \mathrm{p}$.

Desowitz, R.S. \& Fairbain, H., 1955. The influence of temperature on the length of the development of Trypanosome vivax in Glossina palpalis. Ann. Trop. Med. Parasitol. 49:161.

Glasgow, J.P., 1963. The distribution and abundance of tsetse. Pergamon Press, London, $241 \mathrm{p}$.

Glover, P.E., 1961. The tsetse problem in Northern Nigeria. Kaduna Govt printer, Nigeria, $383 \mathrm{p}$.

Gouteux, J.P. \& Larveissiere, C.,1982. Ecology of tsetse flies in the preforest area of Ivory Coast. 4. Dynamics of ecodistribution in the village and its surroundings. Cah. ORSTOM ser. Entomol. Med. Parasitol. 20:199-229.

Gouteux, J.P.; Larveissiere, C. \& Couret, D., 1983. Ecology of tsetse flies in the pre-forest zone of Ivory Coast. 5. Breeding sites. . Cah ORSTOM ser. Entomol. Med. Parasitol. 21:3-12.

Jackson, C.H.N., 1933. The causes and implication of hunger in tsetse flies. Bull. Entomol. Res. 21:491.

Jackson, C.H.N., 1948. The analysis of a tsetse population III, Ann. Eugen. Camb., 14:19-108.

Jordan, A.M., 1989. Man and the changing patterns of the African trypanosomiases. p 47-58. In: Demography and Vector-borne diseases. Service, M.W (ed), CRC Press, BOCA, Raton, Florida, 598 p.

Kalu, A.U., 1991. An outbreak of trypanosomiasis on the Jos Plateau, Nigeria. Trop. Anim. Health. Prod. 23:215-216.

Kernaghan, R.J., 1961. Insecticidal control of the vectors of human trypanosomiais in Northern Nigeria. J. Trop. Med. Hyg. 64:303-309. 
Madubunyi, L.C., 1987. Trypanosome infections in Glossina spp inhabiting peridomestic agroecosystems in Nsukka area, Anambra State, Nigeria. Ann. Trop. Med. Parasitol. 81:319-329.

More, A. \& Richer, M., 2001. Re-emergence of epidemic sleeping sickness in south-sudan. Trop. Med. Int. Health. 6:342-347.

Nash, T.A.M., 1944. A low density of tsetse flies associated with a high density of sleeping sickness. Bull. Entomol. Res. 35:35-51.

Nash, T. A. M., 1960. The effect of different types of contact upon the distribution of T. gambiense sleeping sickness in Nigeria. In: Proceedings of the $7^{\text {th }}$ Meeting of the International Scientific Council for Trypanosomiasis Research and Control/Committee for Technical Cooperation in Africa (ISCTRC/CCTA) 41:191-196.

Nash, T.A.M. \& Page, W.A., 1953. The ecology of Glossina palpalis in Northern Nigeria. Trans. R. Entomol. Soc. Lond. 104:71-169.

Nash, T.A.M. \& McDonald, W.A., 1959. An assessment of the degree of man-fly contact exhibited by Glossina palpalis at water holes in Northern and Southern Nigeria. Ann. Trop. Med. Parasitol. 53:162-165.

Okoth, J.O., 1999. Natural hosts of Glossina fuscipes fuscipes and epidemiological implications for sleeping sickness outbreak in S.E. Uganda. In: Proceedings of the 25th Meeting of the International Scientific Council for Trypanosomiasis Research/Organisation of African Unity, ISCTRC/OAU 120:239-253.

Omoogun, G.A., 1994. The design and construction of the Nitse trap. Insect Sci. Appl. 15: 535-539.

Omoogun, G.A.; Onyiah, J.A.; Edeghere, H.; Elhassan, E.A.; Igweh, A.C.; Thompson, G.A.; Ukah, J.A.C. \& Ikenga, M.A., 1995. The occurrence of Glossina palpalis palpalis (Robineau-Desvoidy) and transmission of Human African Trypanosomiasis (HAT) in Ethiope Local Government Area of Delta State, Nigeria. Entomol. Soc. Nig. Occ. Publ. 30:51-55. 
Onah, J. A., Onyeka, J.O.A. and Tenabe, S.O., 1985. Studies on trypanosome infection rates of Glossina (Diptera: Glossinidae) in Pandam Wildlife Park, Nigeria. Nig. J. Entomol. 6:53-59.

Otieno, L.H., 1982. Transmission of Rhodesian sleeping sickness in Lambwe Valley by peridomestic Glossina pallidipes. Meeting abstract no. 4. Kenya Vet. 6:4.

Penchenier, L. \& Itard, J., 1981. A new technique for the rapid dissection of salivary glands and gut of tsetse. Cah. ORSTOM ser. Entomol. Med. Parasitol. 19:55-57.

Phelphs, R. J. \& Vale, G.A., 1978. Studies on populations of Glossina morsitans morsitans and G. pallidipes (Diptera:Glossinidae) in Rhodesia. J. Appl. Ecol. 15:743-760.

Pollock, J.N., 1982. Training manual for tsetse control personnel. Vol 1. Editor: FAO Publ. No M/P5178/E. 280 p.

Potts, W.H., 1970. Miscellanous techniques used in study of Glossina. In. The African Trypanosomiases. (Mulligan, H.W. Potts, W.H, ed) ODA, George Allen \& Unwin, London, $950 \mathrm{p}$.

Saunders, D.S., 1962. Age determination for female tsetse flies and the age composition of samples of Glossina pallidipes Aust., G. palpalis fuscipes Newst. and G. brevipalis Newst. Bull. Entomol. Res. 53: 579-595.

Stanghellini, A. \& Josenado, T., 2001. The situation of sleeping sickness in Angola: a calamity. Trop. Med. Int. Health 6:330-334.

Toure, S.M., 1974. Note sur quelques particularites dans l'habitat de Glossina palpalis gambiense Vanderplanck observees au Senegal. Rev. Elev. Med. Vet. Pays Trop. 27:81-94.

Wijers, D.J.B., 1958. Factors that may influence the infection rate of Glossina palpalis with Trypanosome gambiense. I. The age of the fly at the time of infected feed. Ann. Trop. Med. Parasitol. 52:385. 